\title{
フーリエ振幅スペクトルの平滑化による 地震入力エネルギーの評価 \\ PREDICTION OF EARTHQUAKE ENERGY INPUT FROM SMOOTHED FOURIER AMPLITUDE SPECTRUM
}

\author{
桑村 仁*, 秋山宏**, 桐野康則*** \\ Hitoshi KUWAMURA, Hiroshi AKIYAMA and Yasunori KIRINO
}

\begin{abstract}
This paper attempted to prove analytically that energy input spectrum of non-linear structures excited by an earthquake motion can be predicted from smoothing the Fourier amplitude spectrum of the base acceleration. The spectral window for the smoothing process is identical to the probability density function of the time-variant vibrational frequency resulting from non-linear hysteresis. It was. found that the increase in damping factor, plastic excursion, or participation of higher modes provides wider spectral windows resulting in more flattened or unaltered energy input spectra due to enhanced smoothing effects.
\end{abstract}

Keywords : earthquke load effect, energy input, Fourier spectrum, spectral smoothing 地震荷重効果, エネルギー入力, フーリエスペクトル，平滑化

1. 序

地震荷重は，構造物の動的応答としてとらえられる荷 重であるため, 地震入力波だけでなく構造物の動的特性 にも支配される荷重である。したがって,. 地震荷重は, その他の荷重, 例えば固定荷重, 積載荷重, 雪荷重, 風 荷重などのように構造特性之無関係に定められる荷重と は全く異質の荷重であるというのが一般的認識である。 このとき, 構造物の動的特性としては, 固有周期, 减衰 定数, 降伏せん断力係数, 復元力特性などが挙げられ, 地震入力波の不確定性とあいまってそれらが複雑に関係 していることが設計用地震荷重の決定を困難にしている と考えられている。

これに対して，地震荷重を一般に使用されている加速 度応答スペクトルではなくエネルギー入力スペクトルで 表現すれば，その困難を克服できるという見解がある。 これは, 地震動による構造物への総エネルギー入力を速 度に換算したもののスペクトル（以下，エネルギー換算 速度応答スペク.トルまたは $V_{E}$ スペクトルと称す）は構 造物の弾性固有周期のみに支配され，それ以外の構造特
性にはほとんど依存しない極めて安定した量となるとい う応答解析結果に基づいており ${ }^{1)}$ ，それをべースに鋼構 造建築物の耐震設計の枠組が研究されてきた2)。

また，エネルギー換算速度応答スペクトルがこのよう に安定した量であるのは，これが地震加速度入力波の フーリエ振幅スペクトル（以下， $|F|$ スペクトルとも 表記する) を平滑化して得られるスペクトルと一致する 傾向があるからであると示唆されている3 ${ }^{3} V_{E}$ スペクト ルは，構造物の応答の結果として得られるものであるの で, 構造物の動的特性の影響を受け, 構造物というフィ ルターを通して出力されたものである。一方， $|F|$ ス ペクトルは，地震波そのものの特性であり，構造物とは 無関係に定まるものである。 $V_{E}$ と $|F|$ に明瞭な対応関 係があるのであれば，地震荷重を他の荷重之同様に構造 特性とは無関係に地震入力波のみから定めることがで き, 設計の観点からは非常に好都合と言える。

そこで, 本研究はエネルギー換算速度応答スペクトル が地震加速度のフーリエ振幅スペクトルとどのような相 関があるかを定量的に調べ，エネルギー換算速度応答ス

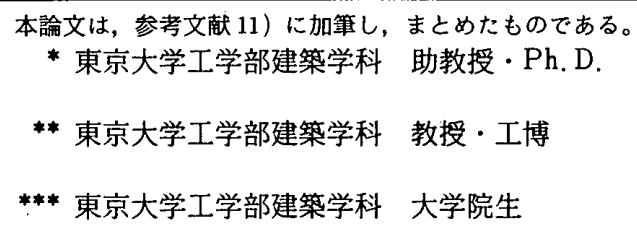

Assoc. Prof,, Dept. of Architecture, Faculty of Engineering, Univ. of Tokyo, Ph. D.

Prof., Dept. of Architecture, Faculty of Engineering, Univ. of Tokyo, Dr. Eng.

Graduate Student, Dept. of Architecture, Faculty of Engineering, Univ. of Tokyo 
ペクトルの設計荷重表現としての妥当性を検討したもの である。

\section{2. 無隇衰弾性 1 質点系における $V_{E}$ と $|\boldsymbol{F}|$ の関係}

減衰のない弾性 1 質点系の $V_{E}$ スペクトルと $|F|$ ス ペクトルは完全に一致するということが知られてい る7。これは本研究の基本となる点であるので, 改めて それを示すと次のようになる。地動加速度 $\ddot{y}(t)$ のフー リエ振幅スペクトルは次式で定義される。

$$
|F(\omega)|=\left|\int_{0}^{t_{0}} \ddot{y}(t) e^{-t \omega t} d t\right|
$$

ここで, $t_{0}$ : 地震動の継続時間

$$
\omega: \text { 円振動数 }
$$

上式の右辺を展開すると，

$$
|F(\omega)|=\sqrt{\left(\int_{0}^{\iota_{0}} \ddot{y}(t) \cos \omega t d t\right)^{2}+\left(\int_{0}^{t_{0}} \ddot{y}(t) \sin \omega t d t\right)^{2}}
$$

一方，無減衰弾性 1 質点系の強制振動方程式は,

$$
m \ddot{x}+m \omega_{0}^{2} x=-m \ddot{y}
$$

ここで, $m:$ 質量

$$
x: \text { 相対変位 }
$$

$\omega_{0}$ : 固有円振動数, $\omega_{0}=\sqrt{k_{0} / m}$

$k_{0}:$ 弹性ばね定数

$\ddot{y}:$ 地震入力加速度

地震終了までの系へのエネルギー入力は，（2）式の左 辺を変位 $x$ に関して積分したものであるので, $d x=$ $\dot{x} d t$ より,

$$
E=\int_{0}^{\iota_{0}} m \ddot{x} \dot{x} d t+\int_{0}^{\iota_{0}} m \omega_{0}^{2} x \dot{x} d t
$$

地震動の入力開始時 $t=0$ における初期条件 $x(0)=\dot{x}(0)$ $=0$ より，上式は次のようになる。

$$
E=\frac{1}{2} m \dot{x}\left(t_{0}\right)^{2}+\frac{1}{2} m \omega_{0}^{2} x\left(t_{0}\right)^{2}
$$

（3）式は，Eが地震終了時におりる系の保有する運動 エネルギーと弾性ひずみエネルギーの和となることを表 している。地震終了時における相対変位と相対速度に関 する Duhamel 積分解を（3）式に代入して整理すると,

$$
\begin{aligned}
E= & \frac{1}{2} m\left(\int_{0}^{t_{0}} \ddot{y}(t) \cos \omega_{0} t d t\right)^{2} . \\
& +\frac{1}{2} m\left(\int_{0}^{t_{0}} \ddot{y}(t) \sin \omega_{0} t d t\right)^{2} .
\end{aligned}
$$

エネルギー換算速度応答スペクトルの定義は,

$$
V_{E}=\sqrt{\frac{2 E}{m}}
$$

これに（4）式を代入すると,

$$
V_{E}=\sqrt{\left(\int_{0}^{L_{0}} \ddot{y}(t) \cos \omega_{0} t d t\right)^{2}+\left(\int_{0}^{t_{0}} \ddot{y}(t) \sin \omega_{0} t d t\right)^{2}}
$$

(1)，（6）式より， $\omega=\omega_{0}$ のとき次式が成り立つ。 $V_{E}=|F|$

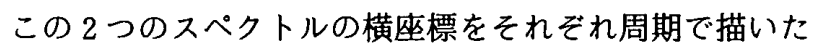
場合, $V_{E}$ スペクトルの横軸は振動系の固有周期 $T_{0}=2$ $\pi / \omega_{0}$ であり, $|F|$ スペクトルの横軸は地震加速度波に 含まれる調和波成分の周期 $T=2 \pi / \omega$ であるので, 両 者は基本的に別のものであるが，それにもかかわらず

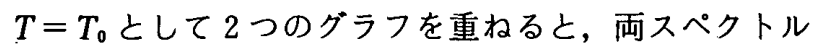
が一致する。

これは，構造物への入力エネルギーは地震動の中から 構造物と同じ周期の波を選び，その波の振幅に支配され るということを意味しており，これは田治見の指摘した 選択共振5) と同じである。さらに重要な点は, 入力波の 位相情報が入力エネルギーに全く影響を与えないことで ある。時間領域で定義される入力加速度波は周波数領域 で定義されるフーリエ掁幅スペクトルとフーリエ位相ス ペクトルの対と 1 対 1 に対応している。にもかかわらず， フーリエ位相スペクトルは入力エネルギーに無関係であ ることを（7）式は表している。フーリエ振幅スペクト ルが同じでもフーリエ位相スペクトルが異なれば, 時間 領域に逆変換された入力加速度波は異なり，加速度の ピーク值やその出現時刻は異なってくる。しかし，この ような加速度波のスパイクは入力エネルギーと理論的な 相関は無いことがわかる。

以上のことから類推されるのは, 振動中に構造物の周 期が減衰や塑性化に伴って変動する場合, それぞれの周 期に対応する波を時々刻々選びながらエネルギーが入力 されるであろうということである。これについての検証 が本研究の課題であり, 次章以降で検討する。

なお，（3）式からわかるように, 総エネルギー入力 は地震終了時における系のエネルギーと等しいので, 無 減衰弾性系の $V_{E}$ スペクトルは残留速度スペクトルと等 しい。したがって, 無減衰弾性系の相対速度応答スペク トルを $S_{\nu}$ とすると, $S_{\nu} \geq V_{E}$ の関係がある6)。しかし， $S_{\nu}$ と $V_{E}$ は細部においては違いがあるがスペクトルの 全体的な形は頑似しているので7), 無減衰系の $V_{E}$ スペ クトルは相対速度応答スペクトルと同じ形状をしている と見てよい。なお， $S_{\nu}$ と $V_{E}$ の違いの原因は， $S_{\nu}$ が入 力波の位相情報の影響を受けるためである。

\section{3. 減衰弾性 1 質点系における $\mathbb{V}_{E}$ と $|\boldsymbol{F}|$ の関係}

3.1 振動周期の時間変動

减衰弾性 1 質点系の自由振動方程式は,

$$
\ddot{x}+2 h \omega_{0} \dot{x}+\omega_{0}^{2} x=0 \text {. }
$$

ここで, $h:$ 減衰定数

これを無減衰弾性 1 質点系の振動方程式と同じ表現にす ると,

$$
\ddot{x}+\omega_{t}^{2} x=0
$$

(8)，(9) 式が等価であるには, 


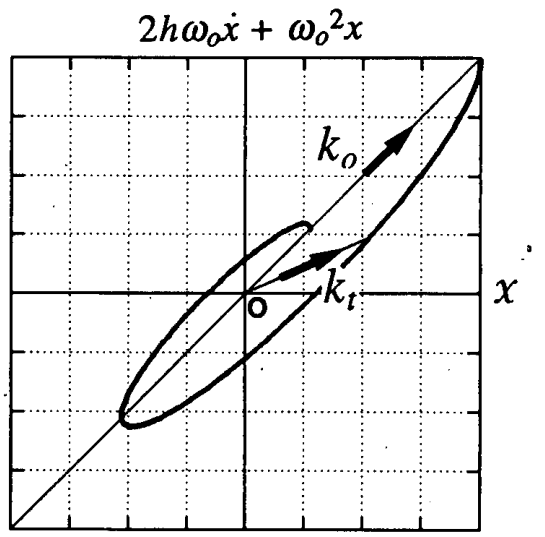

Fig. 1 減衰弾性 1 質点系の履歴カーブ

$$
\omega_{t}^{2}=2 h \omega_{0} \frac{\dot{x}}{x}+\omega_{0}^{2}
$$

ここで， $\omega_{t}$ は減衰弾性 1 質点系の時々刻々変化する固 有円脤動数を表している。（8）式の解は,

$$
x=A e^{-h \omega_{0} t} \sin \left(\omega_{1} t+\phi\right)
$$

ここで, $A, \phi ：$ 初期条件から決まる定数

$\omega_{1}$ : 減衰系の固有円振動数, $\sqrt{1-h^{2}} \omega_{0}$

（11）式を用いて（10）式を書き換えると

$$
\omega_{t}^{2}=\omega_{0}^{2}\left(1-4 h^{2}\right)+2 h \sqrt{1-h^{2}} \omega_{0}^{2} \cot \left(\omega_{1} t+\phi\right)
$$

ここで，1サイクル（時間にして $\left.2 \pi / \omega_{1}\right)$ における $\omega_{t}^{2}$ の時間平均を計算すると，次式が得られる。

$$
\overline{\omega_{t}^{2}}=\frac{1}{2 \pi / \omega_{1}} \int_{0}^{2 \pi / \omega_{1}} \omega_{t}^{2} d t=\left(1-4 h^{2}\right) \omega_{0}^{2} \cong \omega_{0}^{2}
$$

ここで，最後の近似等号は $h \ll 1$ によ。したがって， 時々刻々変化する復元力ばね定数を $k_{t}$ とすると

(Fig. 1 参照)， $\omega_{t}^{2}=k_{t} / m$ の関係から， $k_{t}$ の時間平均 は弾性ばね定数 $k_{0}$ と等しいことが (13) 式からわかる。 つまり，

$$
\bar{k}_{t}=k_{0}
$$

(12) 式を振動数で表示すると, $f_{t}=\omega_{t} / 2 \pi, f_{0}=\omega_{0} / 2$ $\pi$ の関係より,

$$
f_{t}=f_{0} \sqrt{\left(1-4 h^{2}\right)+2 h \sqrt{1-h^{2}} \cot \left(\omega_{1} t+\phi\right)}
$$

ここで, 1 サイクルにおける $f_{t}$ の時間密度を計算する。 $f_{t} / f_{0}$ を確率変数とし, $Z$ で表す。つまり,

$$
Z=\frac{f_{t}}{f_{0}}
$$

$Z$ の確率密度関数を $f_{Z}(z)$ とすると,

$$
\begin{aligned}
f_{z}(z) d z & =P(z \leq Z \leq z+d z) \\
& =P\left(f_{0} z \leq f_{t} \leq f_{0}(z+d z)\right)
\end{aligned}
$$

ここで, $P(）$ は（）内の事象の生起確率を表す。上 式に (15). 式の $f_{t}$ を代入して整理すると,

$$
\begin{aligned}
f_{z}(z) d z & =P\left(\frac{\cot ^{-1}\left(\frac{(z+d z)^{2}-\left(1-4 h^{2}\right)}{2 h \sqrt{1-h^{2}}}\right)-\phi}{\omega_{1}}\right. \\
& \left.\leq t \leq \frac{\cot ^{-1}\left(\frac{z^{2}-\left(1-4 h^{2}\right)}{2 h \sqrt{1-h^{2}}}\right)-\phi}{\omega_{1}}\right)
\end{aligned}
$$

1 サイクルの時間が $2 \pi / \omega_{1}$ であること，および時間は 一様に経過することに注意すると，

$$
\begin{aligned}
f_{z}(z) d z= & -\frac{1}{\frac{2 \pi}{\omega_{1}}} \cdot 2\left(\frac{\cot ^{-1}\left(\frac{(z+d z)^{2}-\left(1-4 h^{2}\right)}{2 h \sqrt{1-h^{2}}}\right)-\phi}{\omega_{1}}\right. \\
& \left.-\frac{\cot ^{-1}\left(\frac{z^{2}-\left(1-4 h^{2}\right)}{2 h \sqrt{1-h^{2}}}\right)-\phi}{\omega_{1}}\right) \\
= & -\frac{1}{\pi} \cdot d\left(\cot ^{-1}\left(\frac{z^{2}-\left(1-4 h^{2}\right)}{2 h \sqrt{1-h^{2}}}\right)\right)
\end{aligned}
$$

結局, 次式を得る。

$$
f_{z}(z)=\frac{1}{\pi} \cdot \frac{1}{1+\left[\frac{z^{2}-\left(1-4 h^{2}\right)}{2 h \sqrt{1-h^{2}}}\right]^{2}} \cdot \frac{2 z}{2 h \sqrt{1-h^{2}}}
$$

$h \ll 1$ を考慮して，簡略化すると，

$$
f_{z}(z)=\frac{1}{\pi} \cdot \frac{1}{1+\left(\frac{z^{2}-1}{2 h}\right)^{2}} \cdot \frac{z}{h} .
$$

(18) 式の $f_{z}(z)$ を Fig. 2 に示す。これからわかるように, 減衰定数が大きいほど変動周波数の確率分布の広がりが 大きくなる。これは, 減衰系を代表する大小 2 つの等価 周期の差が減衰定数に比例するとした文献 4）の置換履 歴系と対応するものである。

$Z$ の全確率は次式で計算される。

$$
A_{z}=\int_{0}^{\infty} \frac{1}{\pi} \cdot \frac{1}{1+\left(\frac{z^{2}-1}{2 h}\right)^{2}} \cdot \frac{z}{h} d z \text {. }
$$

1 サイクル中に $\omega_{t}^{2}<0$ となる時間帯があるので, $f_{Z}(z)$

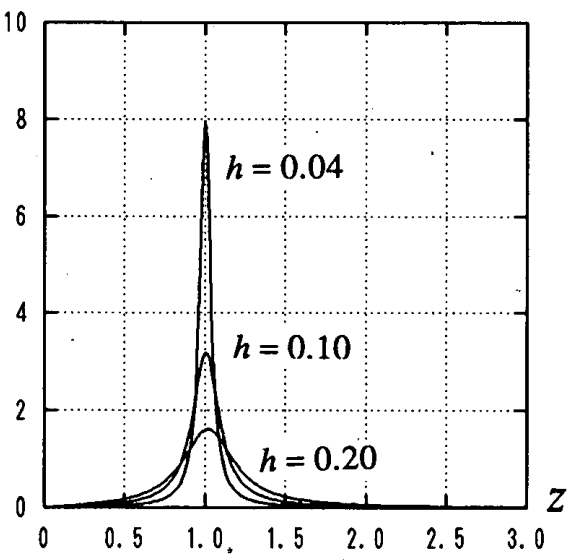

Fig. 2 減衰弾性 1 質点系の $Z=f_{t} / f_{0}$ の確率密度関数 
Table 1 減衰系の確率密度関数の補正值

\begin{tabular}{|l|l|}
\hline $\begin{array}{c}\text { 減衰定数 } \\
h\end{array}$ & $A Z=\int_{0}^{\infty} \frac{1}{\pi} \cdot \frac{1}{1+\left(\frac{z^{2}-1}{2 h}\right)^{2}} \cdot \frac{z}{h} d z$ \\
\hline 0.02 & 0.987 \\
\hline 0.06 & 0.962 \\
\hline 0.10 & 0.937 \\
\hline 0.20 & 0.879 \\
\hline
\end{tabular}

$0 \leq Z \leq \infty$ で定義された $Z$ の全確率はTable 1 に示すよ うに 1 に満たない。この傾向は減衰定数が小さい時はほ とんど問題ないが, 減衰係数が大きくなると補正が必要 である。そこで（18）式を $A_{z}$ で除したものを新たに $Z$ の確率密度関数亡する。

$$
f_{z}(z)=\frac{1}{\pi} \cdot \frac{1}{1+\left(\frac{z^{2}-1}{2 h}\right)^{2}} \cdot \frac{z}{h} \cdot \frac{1}{A_{z}} \text {. }
$$

\section{$3.2 V_{E}$ と平滑化 $|F|$ の関係}

減衰弾性 1 質点系の $V_{E}$ は, $(5)$ 式の定義から応答 解析に基づき次の計算を行うことにより得られる。

$$
V_{E}=\sqrt{-2 \int_{0}^{t_{0}} \ddot{y} \dot{x} d t}
$$

一方，(20）式で与えられる周波数の確率密度関数を スペクトルウインドウとして用い，地震入力加速度の フーリエ振幅スペクトルを平滑化することができる。こ こでの平滑化計算は周波数領域で行い，つまり，周波数 の関数として表示されたフーリエ振幅スペクトルに周波 数の関数として与えられている平滑化関数 (20) 式を乗 じて平滑化フーリエ振幅スペクトルを算定し，最後にこ の平滑化スペクトルを周期の関数に変換した。これに よって得られた平滑化 $|F|$ スペクトルを(21) 式から 得られた $V_{E}$ スペクトルと $h=0.1$ の場合について比較 したのがFig. 3a，b，cである。|F|スペクトルそのも のは凹凸の激しい形状をしているが，(20) 式のスペク トルウインドウによる平滑化 $|F|$ スペクトルはかなり 平坦化され，しかも $V_{E}$ スペクトルとたいへんよく一致 している。ここで用いた地震波は Table 2 に示す 3 種類 の地震波である。さらに，減衰定数を変化させた場合に ついて，両者の相関係数および比の平均を $0.2 \leq T$ $\leq 5.0$ 秒の範囲で調べた結果が Table 3 に示してある。 いずれの場合にも，両者に非常に良い対応関係があるこ とがわかる。

以上より，減衰の存在に起因する復元力ばね定数の時 間的変動, 換言すれば振動周期または周波数の時間的変 動に基づいて決定したウインドウを用いて平滑化した フーリエ振幅スペクトルは, 減衰系の $V_{E}$ スペクトルと 一致するとみなすことができる。したがって，減衰系の $V_{E}$ スペクトルは地動加速度のフーリ工振幅スペクトル

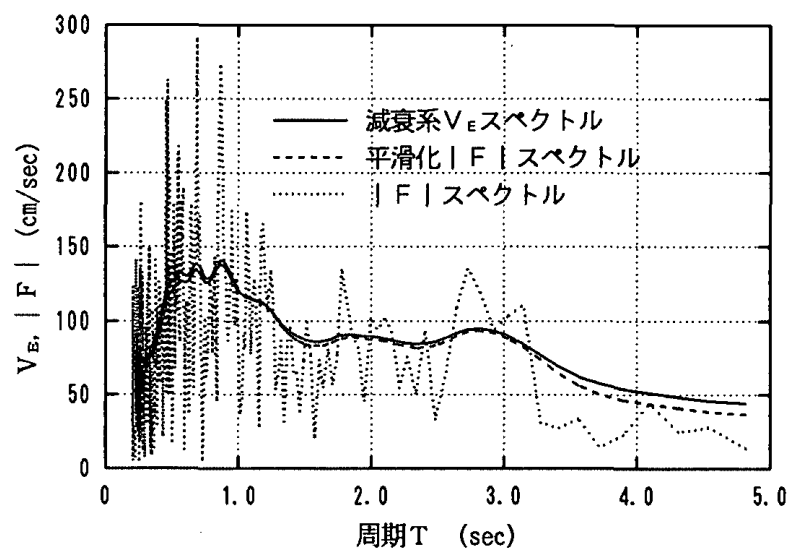

(a) エルセントロ, NS, $h=0.1$

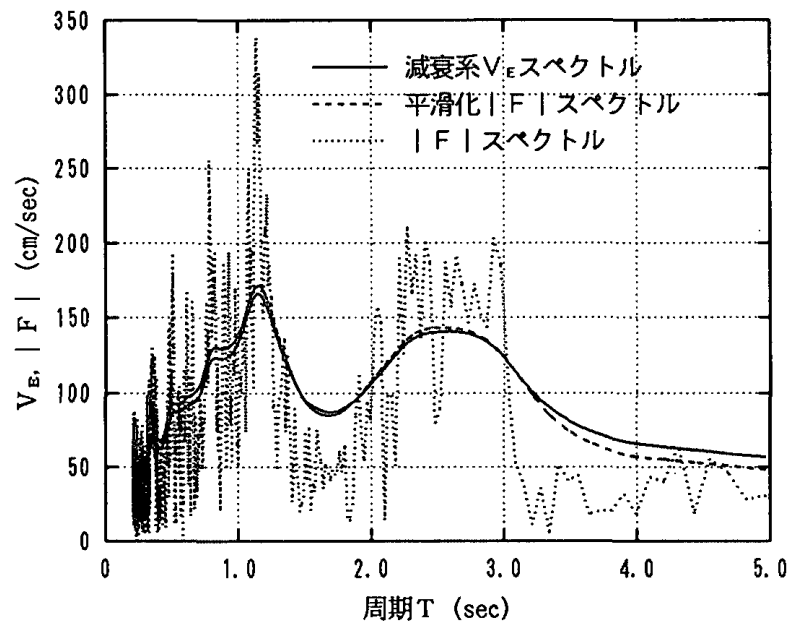

(b) 八戸, $\mathrm{EW}, h=0.1$

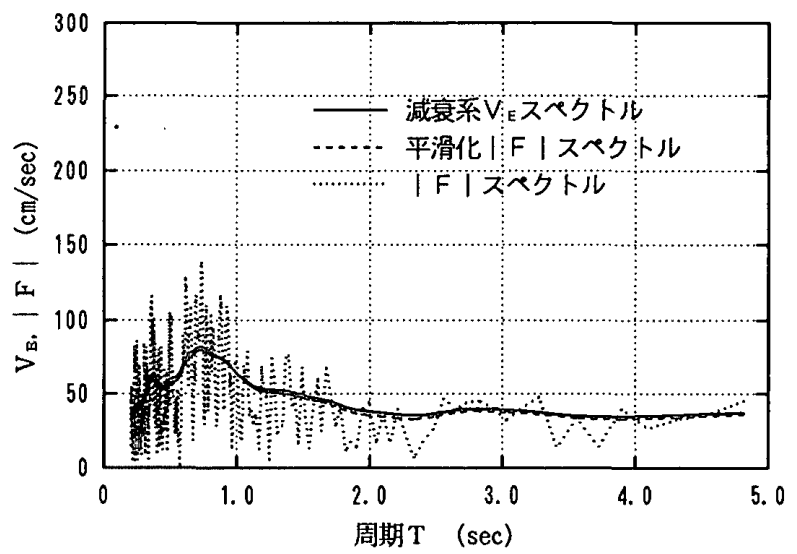

(c) タフト, NS, $h=0.1$

Fig. 3 減衰系の $V_{E}$ スペクトルと平滑化 $|F|$ スペクトルの比較

Table 2 解析に使用した地震波

\begin{tabular}{|l|c|c|c|}
\hline \multicolumn{1}{|c|}{ 地震波 } & $\begin{array}{c}\text { データ 長 } \\
(\mathrm{sec})\end{array}$ & $\begin{array}{c}\text { ピーク加速度 } \\
(\mathrm{gal})\end{array}$ & $\begin{array}{c}\text { 加速度バワーIE } \\
\left(\mathrm{cm}^{2} / \mathrm{sec}^{3}\right)\end{array}$ \\
\hline $\begin{array}{l}\text { El Centro, NS } \\
5 / 18 / 1940\end{array}$ & 54 & 342 & 114,000 \\
\hline $\begin{array}{l}\text { Hachinohe, EW } \\
\text { 5/16/1968 }\end{array}$ & 120 & 183 & 73,500 \\
\hline $\begin{array}{l}\text { Taft, NS } \\
7 / 21 / 1952\end{array}$ & 54 & 153 & 34,100 \\
\hline
\end{tabular}


Table 3 減衰弾性 1 質点系の $V_{E}$ スペクトルと平滑化 $|F|$ スペ クトルの相関 $(0.2 \leq T \leq 5.0 \mathrm{sec})$

\begin{tabular}{|c|c|c|c|}
\hline 地震波 & 堿衰定数 $h$ & $V_{E}$ と $|F|$ の相関保数 & $V_{E} /|F|$ の平均値 \\
\hline \multirow{4}{*}{$\begin{array}{l}\text { エルセントロ } \\
\text { NS }\end{array}$} & 0.02 & 0.999 & 0.981 \\
\hline & 0.06 & 0.996 & 0.969 \\
\hline & 0.10 & 0.992 & 0.957 \\
\hline & 0.20 & 0.982 & 0.933 \\
\hline \multirow{4}{*}{$\begin{array}{l}\text { 八戸 } \\
\mathrm{EW}\end{array}$} & 0.02 & 1.000 & $0: 980$ \\
\hline & 0.06 & 0.999 & 0.961 \\
\hline & 0.10 & 0.997 & 0.945 \\
\hline & 0.20 & 0.995 & 0.913 \\
\hline \multirow{4}{*}{$\begin{array}{l}\text { タフト } \\
\text { NS }\end{array}$} & 0.02 & 0.999 & 0.981 \\
\hline & .0 .06 & 0.995 & 0.970 \\
\hline & 0.10 & 0.990 & 0.959 \\
\hline & 0.20 & 0.975 & 0.937 \\
\hline
\end{tabular}

の凸凹を均した形状をしており，減衰系の $V_{E}$ スペクト ルの上下限值は地動加速度のフーリエ振幅スペクトルの 上下限值の間に存在する。しかも, 诚衰定数が大きいほ ビ, 平滑化のウインドウが広くなるので $V_{E}$ スペクトル の形状はより平坦になり， $V_{E}$ スペクトルの值はより安 定化する。つまり, 減衰系の $V_{E}$ スペクトルは弾性固有 周期の誤差に対してより鈍感になり, その最大值は地震 動固有の強さに支配されると言える。

\section{4. 完全弾塑性 1 質点系における $V_{E}$ と $|\boldsymbol{F}|$ の関係}

\section{1 振動周期の時間変動}

減衰の無い完全弾塑性 1 質点系の自由振動方程式は, 弾性域で,

$$
\ddot{x}+\omega_{0}^{2} x=0
$$

塑性域で,

$$
\ddot{x}+\left(\frac{Q_{\rho}}{m} \cdot \frac{1}{x}\right) x=0
$$

\section{ここで, $Q_{\rho}$ ：降伏せん断力}

(22)，(23）式を比較すると, 塑性域における円振動数 は次式で与えられることがわかる。

$$
\omega_{t}=\sqrt{\frac{Q_{p}}{m} \cdot \frac{1}{x}}
$$

したがって， $\omega_{\mathrm{t}}$ は $x$ とともに時々刻々変化することに

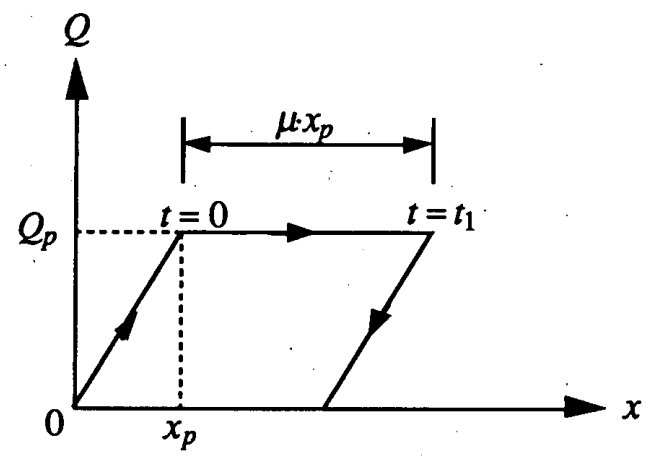

Fig. 4 完全弾塑性系の履歴カーブ (半サイクル)
なる。そこで, Fig. 4 に示す $1 / 2$ サイクルの自由振動に おける塑性域での振動数の変化を調べる。初期条件とし て, $t=0$ で $\dot{x}=\nu_{0}, x=x_{p}$ とすると, (23) 式の解は,

$$
x=-\frac{Q_{p}}{2 m} t^{2}+\nu_{0} t+x_{p}
$$

ここで，Fig. 4 に示すように塑性変形量を $\mu \cdot x_{p}$ とする と, エネルギー保存より,

$$
\frac{1}{2} m \cdot \nu_{0}^{2}=\mu \cdot x_{p} \cdot Q_{\rho}
$$

よって,

$$
\nu_{0}=\sqrt{\frac{2 \mu \cdot x_{p} \cdot Q_{p}}{m}}=\sqrt{2 \mu} \cdot \frac{Q_{p}}{m \omega_{0}}
$$

ここで，次式を適用した。

$$
x_{p}=\frac{Q_{p}}{k_{0}}=\frac{Q_{p}}{m \omega_{0}^{2}}
$$

さらに, $t=t_{1}$ で塑性化が終了するとすれば， $\dot{x}\left(t_{1}\right)=0$ より,

$$
t_{1}=\frac{\sqrt{2 \mu}}{\omega_{0}}
$$

（24）式に（25)，(26)，(27）式を代入し, さらに $\omega_{t}=2$ $\pi f_{t}$ の関係を用いると次式を得る。

$$
f_{t}=\frac{1}{2 \pi} \cdot \frac{1}{\sqrt{-\frac{1}{2}\left(t-\frac{\sqrt{2 \mu}}{2 \pi f_{0}}\right)^{2}+\frac{\mu+1}{\left(2 \pi f_{0}\right)^{2}}}}
$$

ただし，

$$
0<t<\frac{\sqrt{2 \mu}}{2 \pi f_{0}}
$$

および

$$
\frac{f_{0}}{\sqrt{\mu+1}}<f_{t}<f_{0}
$$

（31）式より，塑性化の度合いが大きいほど, つまり $\mu$ が大きいほど振動周波数が低域に広がることがわかる。 これは文献 4）において導入されている置換履歴系の等 価周期が $\mu$ が大きいほよ゙長くなるというのと同じであ る。

$$
Z=f_{t} / f_{0} \text { として, } Z \text { の確率密度関数 } f_{z}(z) \text { を }
$$
式と同様の方法で求めると次の結果が得られる。

$$
f_{z}(z)=\frac{1}{\sqrt{\mu\left(\mu+1-\frac{1}{z^{2}}\right)}} \cdot \frac{1}{z^{3}} .
$$

ただし，

$$
\frac{1}{\sqrt{\mu+1}}<z<1
$$

(32) 式で与えられる振動数の確率密度関数を Fig. 5 に 示す。 $z \rightarrow 1 / \sqrt{\mu+1}$ のとき, $f_{z}(z) \rightarrow \infty$ となるが, $Z$ の全確率は 1 となる。

$4.2 V_{E}$ と平滑化 $|F|$ の関係

(32) 式で与えられる周波数の確率密度関数をウイン ドウとして用い, 地震入力加速度のフーリエ振幅スペク 


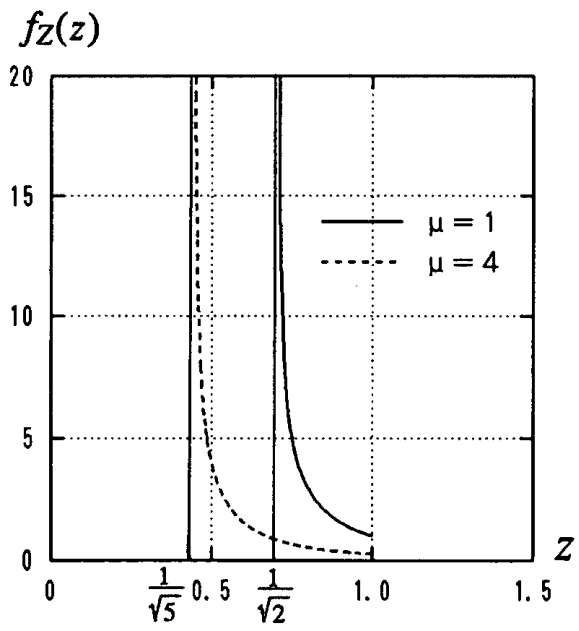

Fig. 5 完全弾望性系の $Z=f_{t} / f_{0}$ の確率密度関数

トルを平滑化することができる。ただし，半サイクルに おける塑性率 $\mu$ (ここではFig. 4 に示すように塑性変 形を弾性限変形で除したもの）は応答結果から定める必 要がある。地震応答中の塑性化回数を $n_{\rho}$ 回として, 各 回における塑性率を $\mu_{i}$ とすると，各塑性化応答におけ る周波数の確率密度関数が（32）式から定義できる。た だし，各確率密度関数の全確率は，その塑性化応答にお けるエネルギー吸収量に比例するように修正が必要であ り，弾性応答におけるエネルギー吸収も考慮する必要が ある。弾性ひすみによる吸収エネルギーは $\frac{1}{2} Q_{p} x_{\rho}$, 各 塑性化応答における吸収エネルギーの合計は $\sum_{i=1}^{n_{p}} \mu_{i} Q_{p} x_{p}$ で表される。したがって，平滑化に用いるウインジウは 次のようになる。

$$
\begin{aligned}
& f_{z}(z)=\frac{1}{2 A} \cdot \delta(z-1) \\
& f_{z}(z)=\frac{1}{\sqrt{\mu_{i}\left(\mu_{i}+1-\frac{1}{z^{2}}\right)}} \cdot \frac{1}{z^{3}} \cdot \frac{\mu_{i}}{A} \\
& \text { 各 } \mu_{i} \text { について } \frac{1}{\sqrt{\mu_{i}+1}}<z<1 \text { のとき }
\end{aligned}
$$
ここで,

$$
A=\frac{1}{2}+\sum_{n=1}^{n_{p}} \mu_{i}
$$

$\delta():$ ディラックのデル夕関数

このようなウインドウを用いて得られた平滑化 $|F|$ ス ペクトルを完全弹塑性系の応答解析に基づいて (21) 式 から得られた $V_{E}$ スペクトルと比較したのが Fig. 6 であ る。同図には，エルセントロ波に対して弾性固有周期 $T=1.0$ 秒における累積塑性変形倍率 $\eta_{1}\left(=\sum_{i=1}^{n \rho} \mu_{i}\right)$ が 5 , 他の周期に対しては $5 / T$ となる場合の結果を描いてあ る。両者はおおむねよく一致している。さらに，エルセ ントロ波について，累積塑性変形倍率 $\eta_{1}$ を変化させた 場合について，両者の相関係数および比の平均を調べた のが Table 4 である。 $\eta_{1}$ の増大に伴い両者の相関は低下

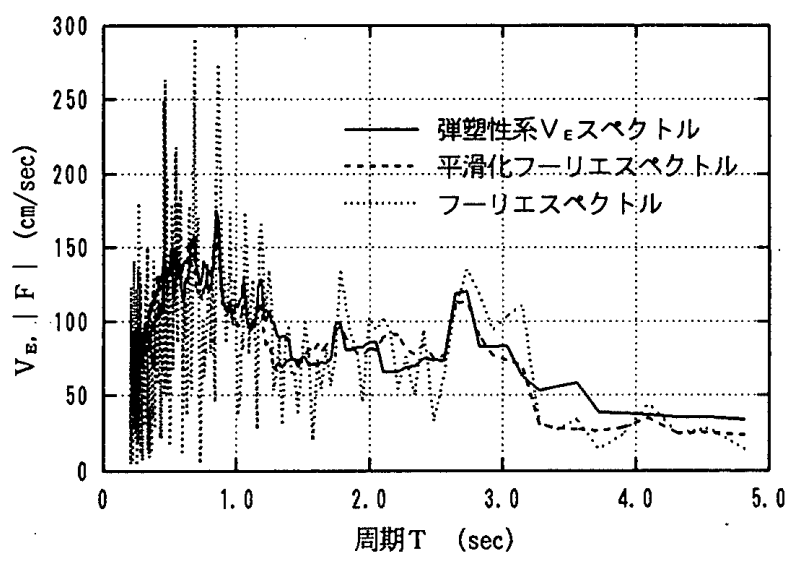

Fig. 6 完全弾塑性系の $V_{E}$ スペクトルと平滑化 $|F|$ スペクトル の比較 (エルセントロ, NS, $\left.\eta_{1}=5\right)$

Table 4 完全弾塑性 1 質点系の $V_{E}$ スペクトルと平滑化 $|F|$ ス ペクトルの相関 $(0.2 \leq T \leq 5.0 \mathrm{sec})$

\begin{tabular}{|l|c|c|c|}
\hline 地霆波 & 累積塑性率 $\eta 1$ & $V E$ V $F$ の相関保数 & $V E / F$ の平均値 \\
\hline \multirow{3}{*}{ エル } & 2 & 0.904 & 0.990 \\
\cline { 2 - 4 } & 2 & 0.907 & 0.962 \\
\cline { 2 - 4 } & 5 & 0.882 & 0.925 \\
\cline { 2 - 4 } & 10 & 0.869 & 0.893 \\
\cline { 2 - 4 } & 20 & \multicolumn{3}{|c}{} \\
\hline
\end{tabular}

するがおおむね良好と言える。

以上より，塑性化に起因する復元力ばね定数の時間的 変動, 換言すれば振動周期または周波数の時間的変動に 基づいて決定したウインドウを用いて平滑化したフーリ 工振幅スペクトルは, 完全弾塑性系の $V_{E}$ スペクトルと おおむね一致するとみなすことができる。したがって， 完全弾塑性系の $V_{E}$ スペクトルは地動加速度のフーリエ 振幅スペクトルの凸凹を均した形状をしており，その上 下限值は地動加速度のフーリエ振幅スペクトルの上下限 值の間に存在する。しかも，塑性化の度合いが大きいほ ビ，平滑化のウインドウが広くなるので $V_{E}$ スペクトル の形状はより平坦になり， $V_{E}$ スペクトルの值はより安 定化する。これは，前節の減衰系と全く同じ現象として とらえることができる。ただし，減衰系の平滑化ウイン ドウが弾性固有振動数を基準にしてほぼ対称なウインド ウであったのに対して，完全弾塑性系の平滑化ウインド ウは弾性固有振動数を基準にしてその低振動数域のみに 広がる低域フィルターである点が異なっている。

\section{5. 無隇衰弾性多質点系における $V_{E}$ と $|\boldsymbol{F}|$ の関係}

無減衰弹性 $n$ 質点系への総エネルギー入力 $E$ の速 度換算を全質量 $M$ を用いて, (5) 式と同様に $V_{E}=$ $\sqrt{2 E / M}$ で定義すると，モーダルアナリシスにより次 式を得る8)。

$$
V_{E}=\sqrt{\sum_{j=1}^{n}\left(\beta_{j}\left|F\left(\omega_{j}\right)\right|\right)^{2}}
$$

ここで, $\left|F\left(\omega_{j}\right)\right|$ は $j$ 次固有円振動数における入力加速 


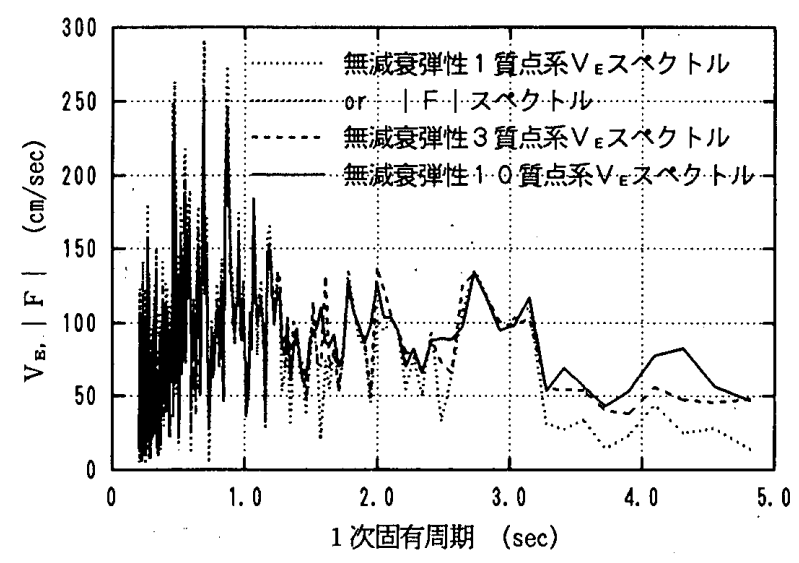

Fig. $7 n$ 質点系の $V_{E}$ スペクトル $(n=1,3,10)$

度のフーリエ振幅值である。 $\beta$,は，モードベクトルに 正規化条件 $[\varphi]^{T}[m][\varphi]=M[1]$ を課して定めた $j$ 次刺激

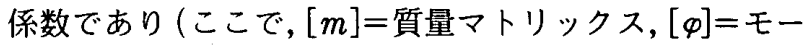
ドマトリックス, $[\varphi]^{T}=[\varphi]$ の転置マトリックス, $M=$ 全質量, [1]=単位マトリックス)，次の等式が成り立つ。

$$
\sum_{j=1}^{n} \beta_{j}^{2}=1
$$

したがって，(37)，(38) 式より

$$
\min \left\|F\left(\omega_{j}\right)\right\| \leq V_{E} \leq \max \left\|F\left(\omega_{j}\right)\right\|
$$

これらの関係は, $V_{E}$ が $\left|F\left(\omega_{1}\right)\right|, \cdots \cdots,\left|F\left(\omega_{n}\right)\right|$ の $\beta_{J} に$ よる一種の重み付け平均であることを意味している。さ らに，(38）式の条件より，無減衰弾性多質点系の $V_{E}$ は, フーリエ振幅スペクトル $|F|$ を $\beta$ ，群輝線ウインドウで 平滑化したものであることがわかる。ただし，このウイ ンドウは一次固有振動数を基準にすると高域フィルター の性質を持っている。

Fig. 7 にせん断型多質点系の $V_{E}$ を質点数 $n=1,3,10$ の場合について描いた。ここでは，振動系の各質点の質 量はすべて等しく，また各層のせん断ばね定数はその層 が支える質量に比例するものとした。質点数の増加に伴 いスペクトルが平滑化される様子がわかるが，減衰系や 弾塑性系ほど平滑化の度合いは大きくない。

\section{VEスペクトルと地震動固有の強さ}

現実の構造物は，構造剛性の非線形性や減衰の存在に より振動中に周期が変化する。したがって，以上の検討 結果から，見実の構造物のエネルギー入力換算速度応答 スペクトル $V_{E}$ は, 多かれ少なかれフーリ工振幅スペク トル $|F|$ を平滑化したものとなる。一般に，地震動加 速度のフーリエ振幅スペクトルを平滑化したものは, 横 軸を周期にすると Fig. 8 に示すようにバイリニアな カーブで近似できることが多い。これは，相対速度応答 スペクトルが多くの地震波についてバイリニアカーブで 近似できること5),10)と同じである。なぜなら，既に述べ たようにフーリエ振幅スペクトルと相対速度応答スペク トルは同じ形をしているからである。Fig.8のバイリニ

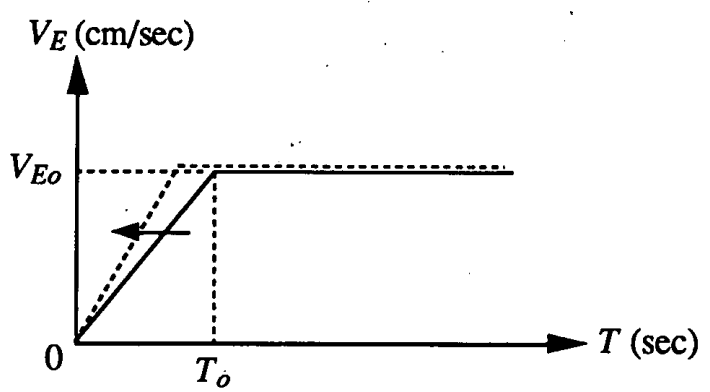

Fig.8 $V_{E}$ スペクトルのバイリニア近似

アカーブの折れ曲がり点の横座標を地震動の卓越周期 $T_{0}$ で定義すれば,

$$
\begin{array}{ll}
V_{E}=\frac{V_{E 0}}{T_{0}} \cdot T . & T \leq T_{0} \text { のとき } \\
V_{E}=V_{E 0} & T>T_{0} \text { のとき }
\end{array}
$$

この性質に着目して， $V_{E}$ スペクトルの上限 $V_{E 0}$ を求 めると次のようになる。まず，Parseval の定理により， 次式が成り立つ。

$$
\int_{0}^{t_{0}} \ddot{y}(t)^{2} d t=\frac{1}{\pi} \int_{0}^{\infty}|F(\omega)|^{2} d \omega
$$

上式の左辺は加速度パワーと呼ばれるもので，これを $I_{E}$ で表す。つまり，

$$
I_{E}=\int_{0}^{t_{0}} \ddot{y}(t)^{2} d t
$$

前章までの検討により，近似的に

$$
V_{E}=\text { smoothed }|F(\omega)| \text {. }
$$

平滑化において,近似的に次の条件が満たされている(本 研究で用いたスペクトルウインドウは対称ウインドウで はないので厳密には成り立たない)。

$$
\int_{0}^{\infty}|F(\omega)|^{2} d \omega=\int_{0}^{\infty}(\text { smoothed }|F(\omega)|)^{2} d \omega
$$

したがって,

$$
I_{E}=\frac{1}{\pi} \int_{0}^{\infty} V_{E}^{2} d \omega=2 \int_{0}^{\infty} V_{E}^{2} \frac{1}{T^{2}} d T .
$$

上式に $V_{E}$ のバイリニア特性，つまり（39）式を代入す ると，次式が得られる。

$$
I_{E}=4 \frac{V_{E 0}^{2}}{T_{0}}
$$

あるいは

$$
V_{E 0}=\frac{\sqrt{I_{E} \cdot T_{0}}}{2} .
$$

これは, 文献 9) において別の方法で求められたものと 一致する。

結局, $V_{E}$ スペクトルは各種の平滑化要因によって, その上限は安定し, その上限値は地震動固有の加速度パ ワーと卓越周期のみで決定され，構造物の特性には依存 しないと言える。なお，平滑化がかなり進行しても平滑 化フーリエスペクトルがバイリニア型とはならない特種 な場合（例えばメキシコ地震におけるようなある特定の 
調和波が極端に卓越するような場合）があるので，その 時には（45）式による上限予測は適切ではない”。また， 弾塑性系の場合には, 平滑化が低減フィルターで行われ るので, Fig. 8 の矢印で示すようにバイリニア型の $V_{E}$ スペクトルの折れ曲がり点が低周期側にシフトする。こ れは，文献 4) で応答解析により明らかにされている。

\section{7. 結 論}

本研究は, 地震動による構造物への入力をエネルギー で表現したとき，その入力量は地震動加速度の平滑化 フーリエ振幅スペクトルから決定することができること を数理解析的に明らかにしたものである。つまり，構造 物への地震入力エネルギーを速度に換算したエネルギー 換算速度応答スペクトル（ $V_{E}$ スペクトル）は，振動中 の構造物の変動周波数の確率密度関数をスペクトルウイ ンドウとして用いて平滑化したフーリエ振幅スペクトル と極めてよく一致することを定量的に示した。減衰の増 大や, 塑性変形の増大, あるいは高層建物の 2 次以上の 固有周期の影響が増大すると, 構造物の振動周期の変動 幅が大きくなるのでそれに伴い平滑化のウインドウが広 くなり $V_{E}$ スペクトルはより平均化するという現象を解 明した。

これらの知見に基づき， $V_{E}$ スペクトルを用いること により地震荷重を構造特性と分離でき，しかも安定した 荷重として扱うことができるという従来からの主張を支 持するに至った。具体的には，与えられた地震動に対す る $V_{E}$ スペクトルが構造物の振動特性のうち弾性固有周 期のみに支配されること，および $V_{E}$ スペクトルがバイ リニア型となる一般的な地震波について $V_{E}$ の上限值は 地震動固有の特性のうち加速度パワーと卓越周期のみか
ら決まり地震動に含まれる位相情報は無関係であること が明らかにされた。

\section{参考文献}

1）加藤 勉, 秋山 宏：強震による構造物へのエネルギ入 力と構造物の損傷, 日本建築学会論文報告集, 第 235 号, pp. 9 18, 1975.9

2）日本建築学会：建築耐震設計における保有耐力と変形性 能 (1990)，鎆構造, pp. 261 337, 1990. 10

3) Kuwamura, H. and Galambos, T.V. : Earthquake Load Effect for Seismic Risk Assessment, Proc. 9 WCEE, Vol. V, pp. 313 318, 1988.8

4）秋山 宏：建築物の耐震極限設計，東大出版，1980.9

5）田治見宏：建築振動学，コロナ社，1973.2

6）大崎順彦：地震動のスペクトル解析入門，鹿島出版会， 1980.4

7) Hudson, D.E. : Some Problems in the Application of Spectrum Techniques to Strong-Motion Earthquake Analysis, BSSA, Vol. 52, No.2, pp. 417 430, 1962.4

8）桐野康則：地震動のフーリエスペクトルとエネルギー入 カスペクトルの相関に関する研究, 東京大学卒業論文, 1992.3

9）桑村 仁：耐震建築物の限界状態と破壊規範式，日本建 築学会構造系論文報告集, 第 387 号, pp. $45 \sim 54$, 1988.5

10) Housner, G.W. : Limit Design of Structures to Resist Earthquake, Proc. WCEE, No. 5, pp.1 13, 1956. 6

11）桐野康則, 桑村 二, 秋山 宏: 地震動のフーリエスペ クトルとエネルギー入カスペクトルの相関に関する研究, 日本建築学会大会学術講演梗概集, pp. $185 \sim 186$, 1992.8

（1992 年 4 月 27 日原稿受理, 1992 年 8 月 25 日採用决定） 